\title{
Evaluation of Emblica officinalis fruit powder as a growth promoter in commercial broiler chickens
}

\author{
A. P. Patel ${ }^{1}$, S. R. Bhagwat ${ }^{1}$, M. M. Pawar ${ }^{1}$, K. B. Prajapati ${ }^{2}$, H. D. Chauhan ${ }^{3}$ and R. B. Makwana ${ }^{3}$
}

1. Department of Animal Nutrition, College of Veterinary Science and Animal Husbandry, Sardarkrushinagar Dantiwada Agricultural University, Banaskantha, Gujarat, India; 2. Livestock Research Station,

Sardarkrushinagar Dantiwada Agricultural University, Banaskantha, Gujarat, India; 3. Department of Livestock Production and Management, College of Veterinary Science and Animal Husbandry, Sardarkrushinagar Dantiwada Agricultural University, Banaskantha, Gujarat, India.

Corresponding author: M. M. Pawar, e-mail: mahespawar@gmail.com, APP: ashokveti@gmail.com, SRB: shekhar.bhagwat@gmail.com, KBP: Kbprajapati.savita@gmail.com, HDC: Hdchauhan1970@rediffmail.com, RBM: rinkeshvets@gmail.com

Received: 12-09-2015, Revised: 02-01-2016, Accepted: 08-01-2016, Published online: 27-02-2016

doi: 10.14202/vetworld.2016.207-210 How to cite this article: Patel AP, Bhagwat SR, Pawar MM, Prajapati KB, Chauhan HD, Makwana RB (2016) Evaluation of Emblica officinalis fruit powder as a growth promoter in commercial broiler chickens, Veterinary World, 9(2): 207-210.

\begin{abstract}
Aim: The present study was conducted to evaluate the dietary addition of Emblica officinalis (Amla) fruit powder as a growth promoter in commercial broiler chickens.

Materials and Methods: An experiment was conducted on 135 commercial broiler chicks (Ven-Cobb 400 strain) divided into three groups with three replicates of 15 chicks each. Three treatment groups were as follows $-\mathrm{T}_{1}$ : Basal diet as per BIS standards; $\mathrm{T}_{2}$ : Basal diet supplemented with $0.4 \%$ of E. officinalis fruit powder; and $\mathrm{T}_{3}$ : Basal diet supplemented with $0.8 \%$ of E. officinalis fruit powder.
\end{abstract}

Results: The average body weights at the end of the $6^{\text {th }}$ week were significantly higher $(p<0.05)$ in groups $T_{2}$ and $T_{3}$ compared to group $T_{1}$. Feed intake, feed conversion ratio and feed cost per kg live weight production were similar among the treatment groups. The net profit per bird was the highest in group $\mathrm{T}_{2}$ (Rs. 19.22/bird) followed by group $\mathrm{T}_{3}$ (Rs. 17.86/bird) and the lowest in group $T_{1}$ (Rs. 14.61/bird).

Conclusion: Based on the results of the present study, it was concluded that dietary addition of E. officinalis (Amla) fruit powder had a positive effect on growth performance and net profit per bird in commercial broiler chickens.

Keywords: broiler chickens, Emblica officinalis, feed conversion ratio, growth performance.

\section{Introduction}

Growth promoters are chemical and biological substances which are added to diet with the aim to improve the growth, utilization of nutrients and in this way realize better production and financial results. Their positive effect can be expressed through better appetite, improved body weight and feed conversion ratio (FCR), stimulation of the immune system and increased vitality, regulation of the intestinal microflora, etc. In any case, expected results of the use of these additives are increased financial returns over the cost of production. Furthermore, due to ban on the use of antibiotic growth promoters in poultry, herbal preparations have been tried as feed additives as an alternative to antibiotics to increase feed efficiency and growth rate in broiler chickens [1].

In the last decade, herbal feed additives have attracted the attention of scientists as useful resource

\footnotetext{
Copyright: Patel, et al. Open Access. This article is distributed under the terms of the Creative Commons Attribution 4.0 International License (http://creativecommons.org/licenses/by/4.0/), which permits unrestricted use, distribution, and reproduction in any medium, provided you give appropriate credit to the original author(s) and the source, provide a link to the Creative Commons license, and indicate if changes were made. The Creative Commons Public Domain Dedication waiver (http://creativecommons.org/ publicdomain/zero/1.0/) applies to the data made available in this article, unless otherwise stated.
}

for improving productivity. Besides, these herbs are natural component and do not have any side effects like residues in meat products. Amla (Emblica officinalis) fruit powder is one of the herbs which have potential to boost broiler production. Amla is extensively cultivated all over India. The fruits of the plants are used in Ayurveda as a potant rasayana (revitalisers, biological response modifiers) in which the amla was added as anti-stress agent. Phyto-chemical analysis of amla fruit powder provided evidence of presence of the medicinally important bioactive compounds which can be exploited beneficially to improve productivity in broilers.

Emblica officinalis (Amla) is one of the richest sources of ascorbic acid, minerals, amino acids, tannins, and phenolic compounds [2]. Rapid growth rate in commercial broilers accelerate the metabolic rate and make them vulnerable to oxidative stress owing to increased free radical generation [3]. Gallic acid and tannic acids are the phenolic acids present in E. officinalis contribute to the antioxidant activity, in addition, to ascorbic acid [4]. Therefore, the present study was conducted to evaluate the dietary addition of E. officinalis (Amla) fruit powder as a growth promoter in commercial broiler chickens. 


\section{Materials and Methods}

\section{Ethical approval}

This research was carried out after approval of Institutional Animal Ethics Committee of College of Veterinary Science and Animal Husbandry, Sardarkrushinagar Dantiwada Agricultural University, Gujarat.

\section{Experimental design}

A total of 1351-day-old unsexed broiler chicks (Ven-Cobb 400 strain) purchased from a local hatchery were weighed and randomly assigned to one of three treatments with three replicates of 15 chicks based on a completely randomized design. Three treatments were as follows $-\mathrm{T}_{1}$ : Basal diet as per BIS standards; $\mathrm{T}_{2}$ : Basal diet supplemented with $0.4 \%$ of $E$. officinalis fruit powder; and $\mathrm{T}_{3}$ : Basal diet supplemented with $0.8 \%$ of $E$. officinalis fruit powder.

\section{Feeding and management procedures}

Broilers were raised on deep litter housing system for 6 weeks. Feed and water were provided ad libitum throughout the experiment. Broilers were fed in three phases, viz., pre-starter (0-10 days), starter (11-21 days), and finisher (22-42 days) ration as per BIS [5] specifications. Chicks were individually weighed at weekly intervals. Feed consumption and FCR (FCR=feed intake/weight gain) were calculated at weekly intervals. Mortality was recorded daily. The feed cost-economics of broiler production in different treatment groups was calculated based on the current market price of various particulars.

\section{Chemical and statistical analysis}

The ingredients and chemical composition of basal diet used during experimental feeding are given in Table-1. Samples of feeds were milled to pass through a $1 \mathrm{~mm}$ sieve and then analyzed for the chemical composition according to standard procedures of the AOAC [6] methods. The experimental data were statistically analyzed using SPSS software (version 16.0, SPSS Inc., Chicago, USA) as per procedures of Snedecor and Cocharan [7]. The significant differences among the tested means were tested with Duncan's multiple range test [8], and significance was declared at $\mathrm{p}<0.05$.

\section{Results and Discussion}

\section{Growth performance}

The data on growth performance is presented in Table-2. The average body weights of the birds at the end of the $6^{\text {th }}$ week were higher $(\mathrm{p}<0.05)$ in groups $\mathrm{T}_{2}(2186.00 \pm 19.48 \mathrm{~g})$ and $\mathrm{T}_{3}(2170.60 \pm 14.62 \mathrm{~g})$ compared to group $\mathrm{T}_{1}(2076.30 \pm 22.27 \mathrm{~g})$. In the present study, the birds supplemented with $E$. officinalis fruit powder at the rate of $0.4 \%$ and $0.8 \%$ had higher $(\mathrm{p}<0.05)$ overall body weights and weekly body weight gain at the end of $6^{\text {th }}$ week compared to un-supplemented group. The higher body weights observed in E. officinalis supplemented groups may
Table-1: Ingredients and chemical composition of basal diet used during experimental feeding.

\begin{tabular}{lccc}
\hline Attributes & Pre-starter & Starter & Finisher \\
\hline Ingredients (\%) & & & \\
Yellow maize & 51.28 & 52.05 & 57.00 \\
Soybean meal & 40.21 & 38.43 & 33.03 \\
Vegetable oil & 4.56 & 5.6 & 6.38 \\
Dicalcium phosphate & 1.93 & 1.97 & 1.71 \\
Common salt & 0.35 & 0.35 & 0.35 \\
Limestone & 0.97 & 1.01 & 0.93 \\
Maduramycine & 0.05 & 0.05 & 0.05 \\
Lipocare & 0.10 & 0.10 & 0.10 \\
L-lysine & 0.17 & 0.15 & 0.14 \\
DL-methionine & 0.15 & 0.15 & 0.07 \\
Vitamin premix & 0.05 & 0.05 & 0.05 \\
Mineral premix ${ }^{3}$ & 0.20 & 0.20 & 0.20 \\
Total & 100.02 & 100.01 & 100.01 \\
Nutrient composition (\%) & & & \\
Dry matter & 94.63 & 94.71 & 94.32 \\
Crude protein & 23.21 & 21.64 & 19.62 \\
Ether extract & 2.75 & 3.46 & 4.20 \\
Crude fiber & 4.98 & 5.03 & 5.01 \\
Total ash & 5.72 & 6.63 & 5.07 \\
ME (kcal/kg) & 2998.2 & 3075.1 & 3185.6 \\
\hline
\end{tabular}

${ }^{1}$ Lecithin treated with co-enzyme, ${ }^{2}$ Provides per $\mathrm{kg}$ of diet: 12,500 IU vitamin A; 2500 IU vitamin $D_{3} ; 12 \mathrm{mg}$ vitamin $\mathrm{E} ; 1.5 \mathrm{mg}$ vitamin $\mathrm{K} ; 1.5 \mathrm{mg}$ vitamin $\mathrm{B}_{1} ; 5 \mathrm{mg}$; vitamin $\mathrm{B}_{2} ; 2 \mathrm{mg}$ vitamin $\mathrm{B}_{6}, 15 \mathrm{mcg}$ vitamin $\mathrm{B}_{12} ; 15 \mathrm{mg}$ niacin, $10 \mathrm{mg}$ pantothenic acid and $0.5 \mathrm{mg}$ folic acid, 3Provides per $\mathrm{kg}$ of diet: $50 \mathrm{mg}$ iron; $10 \mathrm{mg}$ copper; $80 \mathrm{mg}$ zinc; $80 \mathrm{mg}$ manganese; $1 \mathrm{mg}$ iodine and $0.2 \mathrm{mg}$ selenium. ME: Metabolizable energy

be attributed to anabolic and antioxidant effect of ascorbic acid, gallic acid and tannic acids present in E. officinalis [9]. Similar findings were reported by Maini et al. [10], Patil et al. [11], Kumari et al. [12] Patil et al. [13]. In another studies, Sujatha et al. [14] and Kumar et al. [15] reported increase in body weight when birds were supplemented with polyherbal feed premix containing E. officinalis.

\section{Feed intake and FCR}

Feed intake and FCR were non-significant ( $>0.05$ ) among the treatment groups (Table-3). Dietary supplementation of E. officinalisat both levels $(0.4 \%$ and $0.8 \%)$ did not have any adverse $(p=0.307)$ effect on feed intake in broilers.Our findings are in agreement with prior studies $[15,16]$ which demonstrated that supplementation of $E$. officinalis had no effect of feed intake and FCR. In contrastPatil et al. [13] reported that significant increase in feed intake when birds were supplemented with either E. officinalis fruit powder alone or in form of poly-herb.

\section{Return over feedcost}

The cost of feed per kilogram of live weight production was similar among the treatment groups(Table-4). The profit per bird was the highest $(\mathrm{p}<0.05)$ in group $\mathrm{T}_{2}$ (Rs. 19.22/bird) followed by group $\mathrm{T}_{3}$ (Rs. 17.86/bird) and lowest in group $\mathrm{T}_{1}$ (Rs. 14.61/bird). The higher net profit per bird in E. officinalis supplemented groups attributed to higher 
Table-2: Average weekly body weights ( $\mathrm{g} / \mathrm{bird}$ ) and body weight gain $(\mathrm{g})$ of broiler chicks under different treatment groups.

\begin{tabular}{|c|c|c|c|c|}
\hline \multirow[t]{2}{*}{ Weeks } & \multicolumn{3}{|c|}{ Treatments } & \multirow[t]{2}{*}{ Significance } \\
\hline & $\mathrm{T}_{1}$ & $\mathbf{T}_{2}$ & $\mathbf{T}_{3}$ & \\
\hline \multicolumn{5}{|c|}{ Average weekly body weights ( $\mathrm{g} / \mathrm{bird}$ ) } \\
\hline Day old & $47.04 \pm 0.56$ & $46.22 \pm 0.36$ & $46.71 \pm 0.47$ & NS \\
\hline I & $129.49 \pm 2.48$ & $131.93 \pm 2.35$ & $130.47 \pm 1.59$ & NS \\
\hline II & $394.36^{\mathrm{a}} \pm 5.53$ & $425.38^{b} \pm 6.62$ & $423.34^{b} \pm 3.48$ & $0.012 *$ \\
\hline III & $699.73^{a} \pm 8.48$ & $776.76^{b} \pm 13.97$ & $750.32^{b} \pm 6.07$ & $0.016 *$ \\
\hline IV & $1101.50^{a} \pm 14.58$ & $1176.80^{\mathrm{b}} \pm 17.15$ & $1152.60^{b} \pm 10.99$ & $0.032 *$ \\
\hline V & $1583.20^{a} \pm 20.43$ & $1653.90^{\mathrm{b}} \pm 25.13$ & $1642.20^{b} \pm 11.74$ & $0.027 *$ \\
\hline VI & $2076.30^{a} \pm 22.27$ & $2186.00^{\mathrm{b}} \pm 19.48$ & $2170.60^{b} \pm 14.62$ & $0.003 * *$ \\
\hline \multicolumn{5}{|c|}{ Average weekly weight gain $(\mathrm{g})$} \\
\hline I & $82.4 \pm 2.41$ & $85.7 \pm 2.33$ & $83.8 \pm 1.56$ & NS \\
\hline II & $265.5^{\mathrm{a}} \pm 5.92$ & $293.4^{b} \pm 6.79$ & $293.1^{b} \pm 3.69$ & $0.009 * *$ \\
\hline III & $305.4^{\mathrm{a}} \pm 8.13$ & $351.4^{\mathrm{b}} \pm 14.72$ & $327.0^{\mathrm{ab}} \pm 5.98$ & $0.026 *$ \\
\hline IV & $403.2 \pm 12.96$ & $400.0 \pm 19.01$ & $402.3 \pm 11.49$ & NS \\
\hline V & $481.7 \pm 22.33$ & $470.7 \pm 24.48$ & $489.6 \pm 13.27$ & NS \\
\hline VI & $493.1 \pm 25.45$ & $532.1 \pm 25.55$ & $528.4 \pm 11.07$ & NS \\
\hline $0-\mathrm{VI}$ & $2029.3^{\mathrm{a}} \pm 22.33$ & $2139.7^{b} \pm 19.43$ & $2123.8^{\mathrm{b}} \pm 14.56$ & $0.002 * *$ \\
\hline
\end{tabular}

$a, b, c$ Means bearing different superscripts in a row differ significantly $(* p<0.05 ; * * p<0.01)$

Table-3: Average weekly feed intake ( $\mathrm{g} / \mathrm{bird})$ and FCR in broilers under different treatment groups.

\begin{tabular}{|c|c|c|c|c|}
\hline \multirow[t]{2}{*}{ Weeks } & \multicolumn{3}{|c|}{ Treatments } & \multirow[t]{2}{*}{ Significance } \\
\hline & $T_{1}$ & $\mathbf{T}_{2}$ & $\mathbf{T}_{3}$ & \\
\hline \multicolumn{5}{|c|}{ Average weekly feed intake ( $\mathrm{g} / \mathrm{bird})$} \\
\hline I & $113.9 \pm 3.12$ & $116.1 \pm 1.12$ & $114.0 \pm 0.45$ & NS \\
\hline II & $396.5 \pm 9.23$ & $419.6 \pm 11.58$ & $416.4 \pm 4.07$ & NS \\
\hline III & $501.6^{\mathrm{a}} \pm 9.45$ & $536.5^{\mathrm{b}} \pm 1.18$ & $510.0^{\mathrm{a}} \pm 4.53$ & $0.016^{*}$ \\
\hline IV & $693.3 \pm 3.10$ & $693.0 \pm 6.10$ & $697.3 \pm 5.61$ & NS \\
\hline V & $898.5 \pm 19.30$ & $855.2 \pm 42.34$ & $880.8 \pm 18.74$ & NS \\
\hline VI & $1018.2^{\mathrm{a}} \pm 15.60$ & $1087.9^{\mathrm{b}} \pm 7.77$ & $1071.0^{b} \pm 11.83$ & $0.018 *$ \\
\hline $0-\mathrm{VI}$ & $3622.1 \pm 38.54$ & $3708.4 \pm 45.34$ & $3689.4 \pm 26.89$ & NS \\
\hline \multicolumn{5}{|c|}{ Average weekly FCR } \\
\hline $\mathrm{I}$ & $1.38 \pm 0.03$ & $1.36 \pm 0.05$ & $1.36 \pm 0.04$ & NS \\
\hline II & $1.49 \pm 0.04$ & $1.43 \pm 0.01$ & $1.42 \pm 0.01$ & NS \\
\hline III & $1.64^{b} \pm 0.01$ & $1.53^{\mathrm{a}} \pm 0.04$ & $1.56^{\mathrm{a}} \pm 0.01$ & $0.034 *$ \\
\hline IV & $1.72 \pm 0.01$ & $1.73 \pm 0.02$ & $1.73 \pm 0.02$ & NS \\
\hline V & $1.86 \pm 0.02$ & $1.82 \pm 0.03$ & $1.80 \pm 0.01$ & NS \\
\hline VI & $2.06 \pm 0.03$ & $2.05 \pm 0.01$ & $2.03 \pm 0.01$ & NS \\
\hline $0-\mathrm{VI}$ & $1.80 \pm 0.02$ & $1.75 \pm 0.02$ & $1.74 \pm 0.01$ & NS \\
\hline
\end{tabular}

$a, b, c$ Means bearing different superscripts in a row differ significantly $(p<0.05)$. FCR $=$ Feed conversion ratio

Table-4: Economics of broiler production and mortality in different treatment groups.

\begin{tabular}{lccc}
\hline Particulars & \multicolumn{3}{c}{ Treatments } \\
\cline { 2 - 4 } & $\mathbf{T}_{\mathbf{1}}$ & $\mathbf{T}_{\mathbf{2}}$ & $\mathbf{T}_{\mathbf{3}}$ \\
\hline Feed cost/kg live weight & 45.36 & 44.51 & 45.00 \\
production (Rs.) & & & \\
Net profit/bird (Rs.) & 14.61 & 19.22 & 17.86 \\
Mortality (\%) & 4.44 & 2.22 & 2.22 \\
\hline
\end{tabular}

body weights compared to the un-supplemented group and similar feed intakes among all the treatment groups.

Mortality

The mortality was $4.4 \%, 2.2 \%$ and $2.2 \%$ in $\mathrm{T}_{1}$, $\mathrm{T}_{2}$ and $\mathrm{T}_{3}$ groups, respectively (Table- 3 ). The data indicated that the percent mortality is well within the normal limit, i.e., below 5\%. However, the percent mortality in E. officinalis fruit powder supplemented groups $\left(\mathrm{T}_{2}\right.$ and $\left.\mathrm{T}_{3}\right)$ were lower indicating better livability of birds as compared to $\mathrm{T}_{1}$ group, which may be due to immune-modulatory property of bioactive compounds present in E. officinalis. Similarly, Kumar and Singh [17] reported that mortality was reduced in birds supplemented with either E. officinalis fruit powder or its mixture with other herbs.

\section{Conclusion}

Results indicated that dietary addition of $E$. officinalis (Amla) fruit powder at the rate of $0.4 \%$ and $0.8 \%$ had higher growth rate and net profit per bird in commercial broiler chickens. Though E. officinalis supplementation had shown positive response in the present study, but it needs to be tested at different supplemental levels and in different ration compositions to get the best results.

\section{Authors' Contributions}

SRB and MMP designed and supervised the experiment. APP carried out the experimental work. 
RBM carried out laboratory analysis of feed samples. MMP, KBP and HDC did the data analysis and drafted the manuscript. All authors read and approved the final manuscript.

\section{Acknowledgments}

The authors acknowledge the facilities and financial support provided for the present study from Director of Research, Sardarkrushinagar Dantiwada Agricultural University, Sardarkrushinagar, Banaskantha, Gujarat, India.

\section{Competing Interests} interests.

The authors declare that they have no competing

\section{References}

1. Toghyani, M., Tavalaeian, E., Landy, N., Ghalamkari, Z. and Radnezhad, H. (2011) Efficiency of different levels of Saturej hortensis L. (Savoery) in comparison with an antibiotic growth promoter on performance, carcass traits, immune responses and serum biochemical parameters in broiler chickens. Afr. J. Biotechnol., 10: 13318-13323.

2. Yokozawa, T., Kim, Y.H., Kim, J.H., Tanaka, T., Sugino, H., Okubo, T., Chichu, D. and Juneja, R.L. (2007) Amla (Emblica officinalis Gaertn) attenuates age related renal dysfunction by oxidative stress. J. Agric. Food Chem., 55: 7744-7752.

3. Feng, J., Zhang, M., Zheng, S., Xie, P. and Ma, A. (2008) Effects of high temperature on multiple parameters of broilers in vitro and in vivo. Poult. Sci., 87: 2133-2139.

4. Suresh Kumar, G., Nayak, H., Shylaja, M.D. and Salimath, P.V. (2006) Free and bound phenolic antioxidants in Amla (Emblica officinalis) and turmeric (Curcuma longa). J. Food Compos. Anal., 19: 446-452.

5. BIS. (1992) Indian Standards: Poultry Feed Specifications. $4^{\text {th }}$ Revision. Bureau of Indian Standards, New Delhi.

6. AOAC. (1995) Association of Official Analytical Chemists.
Official Methods of Analysis. 16 $6^{\text {th }}$ ed. Association of Official Analytical Chemists, Washington, DC, USA.

7. Snedecor, G.W. and Cocharan, W.G. (1989) Statistical Methods. $8^{\text {th }}$ ed. Affiliated East West Press Pvt. Ltd., New Delhi, India.

8. Duncan, D.B. (1955) Multiple range and multiple F tests. Biometrics, 11: 1-42.

9. McDowell, L.R., editor. (1989) Vitamins in Animal Nutrition. Comparative Aspects to Human Nutrition. Vitamin A and E. Academic Press, London. p93-131.

10. Maini, S., Rastogi, S.K., Korde, J.P., Arun, M.K. and Shukla, K.K. (2007) Evaluation of oxidative stress and amelioration through certain antioxidants in broilers during summer. J. Poult. Sci., 44: 339-347.

11. Patil, R.G., Kulkarni, A.N., Bhutkar S.S. and Korake, R.L. (2012) Effect of different feeding levels of Emblica officinalis (Amla) on performance of broilers. Res. J. Anim. Husbandry Dairy Sci., 3:102-04.

12. Kumari, M., Wadhwa, D., Sharma, V.K. and Sharma, A. (2012) Effect of Amla (Emblica officinalis) pomace feeding on growth performance of commercial broilers. Indian $J$. Anim. Nutr., 29: 388-392.

13. Patil, A.S., Wankhede, S.M. and Kale, V.R. (2014) Effect of Emblica officinalis (Amla) and vitamin $\mathrm{E}$ addition in diet on growth performance of broiler chicken reared under nutritional stress. Indian J. Anim. Nutr., 31: 389-392.

14. Sujatha, V., Korde, J.P., Rastogi, S.K., Maini, S., Ravikanth, K. and Rekhe, D.S. (2010) Amelioration of heat stress induced disturbances of the antioxidant defense system in broilers. J. Vet. Med. Anim. Health, 2:18-28.

15. Kumar, M., Sharma, R.K., Chaudhari, M. and Jakhar, A. (2013) Effect of Indian gooseberry and multi-enzyme supplementation on the performance of broilers during hot weather. Haryana Vet., 52: 66-68.

16. Sanjyal, S. and Sapkota, S. (2011) Supplementation of broilers diet with different sources of growth promoters. Nepal J. Sci. Technol., 12: 41-50.

17. Kumar, M. and Singh, K.C.P. (2005) Effect of supplementation of herbal product on the production potential of chickens. In: XXII Annual Conference of IPSA and National Symposium, 02-04 February, Hyderabad, India. p69. 